11 World Health Organisation. International classification of diseases. 9th Revision, 1975. Vol 1. Geneva: WHO, 1977.

12 Isles CG, Walker LM, Beevers GD, et al. Mortality in patients of the Glasgow blood pressure clinic. Fournal of Hypertension 1986;4:141-56.

13 Cox DR. Regression models and life tables. Journal of the Royal Statistical Society $(B)$ 1972;34: 187-220.

14 International Collaborative Group. Circulating cholesterol level and risk of death from cancer in men aged 40-69 years. FAMA 1982;248:2853-9.

15 Alderson MR, Bayliss RIS, Clarke CA, Whitfield AGW. Death certification. BrMed f 1983;287:444-5.

16 World Health Organisation. World health statistical annual 1986. Geneva: WHO, 1987 .

17 Leren P. The Oslo diet-heart study-11 year report. Circulation 1970;42: 935-42.

18 Turpeinen $\mathrm{O}$, Karvonen MJ, Pekkarinen M, Miettinen M, Elosuo R, Paavilainen E. Dietary prevention of coronary heart disease: the Finnish mental hospital study. Int $\mathcal{F}$ Epidemiol 1979;8:99-118.

19 Research Committee. Low fat diet in myocardial infarction: a controlled trial. Lancet 1965; ii:501-4.

20 Dayton S, Pearce ML, Goldman H, et al. Controlled trial of a diet high in unsaturated fat for prevention of atherosclerotic complications. Lance 1968;ii:1061-2.

21 Medical Research Council Research Committee. Controlled trial of soya bean oil in myocardial infarction. Lancet 1968;ii:693-700.

22 Committee of Principal Investigators. A co-operative trial in the primary prevention of ischaemic heart disease using clofibrate. Br Heart $\mathcal{f}$ 1978;40: 1069-118.

23 Lipid Research Clinics Program. The lipid research clinics coronary primary prevention trial results. 1 . Reduction in incidence of coronary heart disease. JAMA 1984;251:351-64.

24 Canner PL, Berge KG, Wenger NK, et al. Fifteen year mortality in coronary drug project patients: long term benefit with niacin. $\mathcal{F}$ Am Coll Cardiol 1986;8:1245-55.

25 Blankenhorn DH, Nessim SA, Johnson RL, Sanmarco ME, Azen SP, Cashin-Hemphill L. Beneficial effects of combined colestipol-niacin therapy on coronary atherosclerosis and coronary venous bypass grafts. $尹 A M A$ 1987;257:3233-40.

26 Helsinki Heart Study. Primary prevention trial with gemfibrozil in middle aged men with dyslipidaemia. N Engl f Med 1987;317:1237-45.

27 Westlund $K$, Nicolaysen R. Ten year mortality and morbidity related to serum cholesterol. Scand f Clin Lab Invest 1972;30(suppl 127):3-24.

28 Dyer AR, Stamler J, Paul O, et al. Serum cholesterol and risk of death from cancer and other causes in three Chicago epidemiological studies. $f$ Chronic Dis $1981 ; 34: 249-60$

29 Yaari S, Goldbourt U, Evan-Zohar S, et al. Associations of serum high density lipoprotein and total cholesterol with total, cardiovascular and cance mortality in 7 year prospective study of 10,000 men. Lancet 1981;i:1011-4

30 Thomas CB, Duszynski KR, Schaffer JW. Cholesterol levels in young adulthood and subsequent cancer: a preliminary note. Johns Hopkins Medical foumal 1982;150:89-94.

31 Hiatt RA, Friedman GD, Bawol RD, et al. Breast cancer and serum cholesterol. $\mathcal{F} N C I$ 1982;68:885-9.
32 Salonen JT. Risk of cancer and death in relation to serum cholesterol: a longitudinal study in an eastern Finnish population with high overal cholesterol level. Am f Epidemiol 1982;116:622-30.

33 Kark GD, Smith AH, Hames CG. The relationship of serum cholesterol to the incidence of cancer in Evans County, Georgia. I Chronic Dis 1980;33: 311-22.

34 Beaglehole R, Foulkes MA, Prior IAM, et al. Cholesterol and mortality in New Zealand Maoris. Br Med f 1980;280:285-7.

35 Cambien F, Ducimetiere P, Richard J. Total serum cholesterol and cancer mortality in a middle aged male population. Am $\mathcal{F}$ E pidemiol 1980;112: 388-94.

36 Rose G, Shipley MJ. Plasma lipids and mortality, a source of error. Lancet $1980 ; 1: 523-6$

37 Williams RR, Sorlie PD, Feinleib M, et al. Cancer incidence by levels of cholesterol. FAMA 1981;245:247-52

38 Kozarevic D, McGee D, Vojvodic N, et al. Serum cholesterol and mortality: the Yugoslavian cardiovascular diseases study. Am $\mathcal{F}$ Epidemiol 1981;114: 21-8.

39 Garcia-Palmieri MR, Sorlie PD, Costas R, et al. An apparent inverse relationship between serum cholesterol and cancer mortality in Puerto Rico. Am f Epidemiol 1981;114:29-40.

40 Kagan A, McGee DL, Yano K, et al. Serum cholesterol and mortality in a Japanese-American population: the Honolulu heart program. $A m \mathcal{J}$ Epidemiol 1981;114:11-20.

41 Wallace RB, Rost C, Burmeister LF, et al. Cancer incidence in humans: relationship to plasma lipid and relative weight. $f N C I$ 1982;68:915-8.

42 Peterson B, Trelle E. Premature mortality in middle aged men: serum cholesterol as a risk factor. Klin Wochenschr 1983;63:795-801.

43 Hiatt RA, Fireman BH. Serum cholesterol and the incidence of cancer in a large cohort. $\mathcal{F}$ Chronic Dis 1986;39:861-70.

44 Schatzkin A, Hoover RN, Taylor PR, et al. Serum cholesterol and cancer in the NHANES I epidemiologic follow up study. Lancet 1987;ii:298-301.

45 Tornberg SA, Holm LE, Carstensen JM, Eklund GA. Risks of cancer of the colon and rectum in relation to serum cholesterol and beta lipoproteins. N Engl f Med 1986;315:1629-33.

46 Kark JD, Smith AH, Hames CG. Serum retinol and the relation between serum cholesterol and cancer. Br Med f 1982;284:152-4.

47 Oliver MF. Serum cholesterol-the knave of hearts and the joker. Lancet $1981 ;$ ii: $1090-5$.

48 Oliver MF. Reducing cholesterol does not reduce mortality. 7 Am Coll Cardiol 1988;12:814-7.

49 Ederer F, Leren $P$, Turpeinen $O$, Frantz ID. Cancer among men on cholesterol lowering diets. Lancet 1971;ii:203-6.

50 Report of WHO Expert Committee. Prevention of coronary heart disease. WHO Tech Rep Ser 1982; No 678 .

51 Oliver MF. Should we not forget about mass control of coronary risk factors? Lancet 1983; ;:37-8.

52 British Cardiac Society Working Group on Coronary Prevention. Conclusions and recommendations. Br Heart $\mathcal{F}$ 1987; 57:188-9.

(Accepted 31 fanuary 1989)
Cavendish Clinic, 21 Wellington Road, London NW8 9SQ

J C Stevenson, MRCP, consultant endocrinologist B Lees, BSC, scientific officer M Devenport, MB, clinical research assistant

M P Cust, MRCOG, clinical research fellow

K F Ganger, MRCOG, clinical research fellow

Correspondence to: $\mathrm{Dr}$ Stevenson.

BrMed $\mathcal{J}$ 1989;298:924-8

\section{Determinants of bone density in normal women: risk factors for future osteoporosis?}

\author{
J C Stevenson, B Lees, M Devenport, M P Cust, K F Ganger
}

important. None, however, could predict satisfactorily women at future risk for osteoporosis.

Direct measurements of bone density in the clinically relevant sites are necessary to determine which women should receive preventive treatment for postmenopausal osteoporosis. This would help make such treatment more cost effective.

\section{Introduction}

Two main factors determine a woman's susceptibility to postmenopausal osteoporosis. Firstly, there is the peak adult bone mass attained, and secondly, there is the subsequent bone loss. A primary cause of bone loss is the decline of ovarian function associated with the menopause. ${ }^{1-4}$ It has been proposed, however, that osteoporosis of the proximal femur is not a direct result of the menopause. ${ }^{5}$ Controversy also exists as to when the peak adult bone mass is attained and whether appreciable loss of bone occurs before the menopause. ${ }^{16-9}$ In addition, the importance of the influence of certain lifestyle factors on the skeleton, and whether increased risk for osteoporosis can be predicted from these, is not established. The ability to predict the occurrence of osteoporosis is all important for selecting patients for preventive treatment so that unnecessary treatment can be avoided. 
We investigated bone density and its determinants in healthy women by using a modern measurement technique. Bone density thus measured is directly related to the incidence of fractures. ${ }^{10} 11$ In contrast to most previous studies we measured bone density in the two anatomical sites most clinically relevant to postmenopausal osteoporosis, the spine and the proximal femur.

\section{Patients}

We studied 284 white volunteers comprising 112 premenopausal women (median age $34 \cdot 1$ years, range 21-52) and 172 postmenopausal women (median age 53.4 years, range $28-68$ ). All were in apparent good health, and none was taking any drugs that were known to influence bone or calcium metabolism.

A true premenopausal state was judged to be the presence of a normal and regular menstrual cycle and an absence of menopausal symptoms in each case. A true postmenopausal state was judged to be the absence of menstrual periods for at least six months, confirmed in nearly all women by measuring circulating gonadotrophin concentrations.

\section{Methods}

For each volunteer physical details and information about lifestyle were recorded. These included age, height, weight, age at menarche, age at menopause, gravidity, parity, and whether or not they had breast fed after a pregnancy. The number of years of oral contraceptive use was recorded as was the current weekly alcohol intake (in grams of ethanol). The women were asked if they currently smoked or had smoked in the past, and the lifetime total number of packets of cigarettes smoked was calculated. An estimate of dietary calcium intake was derived from the current consumption of dairy products. Each woman was asked whether she currently participated in regular exercise and whether there was a family history of osteoporosis.

Bone density measurements-Bone density was measured by dual photon absorptiometry with a Lunar DP3 (Lunar Radiation Corp) which incorporated a gadolinium-153 source and used $8 \mathrm{~mm}$ detector collimation. ${ }^{12}$ Precision in vivo was determined by performing two or three measurements in 20 volunteers (five men, median age 31 , range $28-38,15$ women, median age 35 , range $24-60$ ). The median interval

TABLE I-Mean (SD) bone density, measurement differences, and measurement precision

\begin{tabular}{lcccc}
\hline & Femoral neck & Ward's triangle & Trochanteric region & Vertebrae L 2-4 \\
\hline Bone density $\left(\mathrm{g} / \mathrm{cm}^{2}\right)$ & $0.97(0 \cdot 13)$ & $0 \cdot 89(0.21)$ & $0 \cdot 82(0 \cdot 13)$ & $1 \cdot 24(0 \cdot 12)$ \\
No of volunteers & 13 & 13 & 13 & 18 \\
No of measurements & 30 & 30 & 30 & 44 \\
Measurement differences $\left(\mathrm{g} / \mathrm{cm}^{2}\right)$ & $0.004(0.024)$ & $0.010(0.036)$ & $0.016(0.027)$ & $0.002(0.030)$ \\
Coefficient of variation & $1 \cdot 38(0.94)$ & $2 \cdot 48(1.06)$ & $2 \cdot 70(2 \cdot 45)$ & $1 \cdot 14(1.00)$
\end{tabular}

TABLE II - Mean (SD) bone density and correlation with age and time since menopause in premenopausal and postmenopausal women

\begin{tabular}{|c|c|c|c|c|}
\hline & Femoral neck & Ward's triangle & Trochanteric region & Vertebrae L 2-4 \\
\hline \multicolumn{5}{|c|}{ Premenopausal women } \\
\hline Mean bone density $\left(\mathrm{g} / \mathrm{cm}^{2}\right)$ & $0.97(0 \cdot 12)$ & $0.92(0 \cdot 16)$ & $0.79(0.11)$ & $1 \cdot 25(0 \cdot 12)$ \\
\hline Correlation with age: & & & & \\
\hline $\mathrm{r}$ & -0.33 & -0.41 & $-0 \cdot 21$ & -0.09 \\
\hline $\mathrm{p}$ & $=0.001$ & $<0.001$ & $<0.05$ & NS \\
\hline \multicolumn{5}{|c|}{ Postmenopausal women } \\
\hline Mean bone density $\left(\mathrm{g} / \mathrm{cm}^{2}\right)$ & $0.87(0 \cdot 13)$ & $0.76(0.16)$ & $0.75(0.12)$ & $1 \cdot 15(0 \cdot 16)$ \\
\hline $\begin{array}{l}\text { Correlation with age: } \\
r \\
\mathrm{p}\end{array}$ & $\begin{array}{l}-0.24 \\
<0.005\end{array}$ & $\begin{array}{l}-0.27 \\
<0.001\end{array}$ & $\begin{array}{c}-0.11 \\
\text { NS }\end{array}$ & $\begin{array}{c}-0.11 \\
\text { NS }\end{array}$ \\
\hline \multicolumn{5}{|l|}{$\begin{array}{l}\text { Correlation with time since } \\
\text { menopause: }\end{array}$} \\
\hline $\mathrm{r}$ & $-0 \cdot 28$ & -0.31 & $-0 \cdot 23$ & $-0 \cdot 20$ \\
\hline $\mathrm{p}$ & $<0.001$ & $<0.001$ & $<0.005$ & $<0.025$ \\
\hline
\end{tabular}

TABLE III - Mean (SD) or median (range) values of risk factors

\begin{tabular}{lcc}
\hline & $\begin{array}{c}\text { Premenopausal } \\
\text { women }\end{array}$ & $\begin{array}{c}\text { Postmenopausal } \\
\text { women }\end{array}$ \\
\hline Age (years) & $34 \cdot 8(7 \cdot 1)$ & $52 \cdot 9(5 \cdot 6)$ \\
Time since menopause (years) & & $3 \cdot 0(0-20)$ \\
Height $(\mathrm{cm})$ & $165(7)$ & $163(6)$ \\
Weight $(\mathrm{kg})$ & $60 \cdot 9(7 \cdot 3)$ & $62 \cdot 9(7 \cdot 9)$ \\
Gravidity & $1 \cdot 0(0-7)$ & $2 \cdot 4(0-8)$ \\
Parity & $0 \cdot 7(0-8)$ & $1 \cdot 9(0-6)$ \\
Use of oral contraceptive (years) & $6 \cdot 2(5 \cdot 0)$ & $0 \cdot 04(0-20)$ \\
Calcium intake (g/day) & $598(285)$ & $619(274)$ \\
Alcohol intake (g/week) & $5 \cdot 9(0-50)$ & $3 \cdot 1(0-50)$ \\
Cigarette consumption (packs) & $0 \cdot 3(0-23725)$ & $0 \cdot 5(0-21900)$ \\
\hline
\end{tabular}

between measurements was six weeks (range 2-85 weeks), and the study covered a period of 21 months (which included a change in isotope source).

Vertebral measurements - Vertebral bone density was measured in L2-4, and the mean value was expressed as $\mathrm{g} / \mathrm{cm}^{2}$. In 11 women this measurement was not obtained.

Proximal femur measurements-Bone density was measured in the femoral neck, Ward's triangle, and the trochanteric region. In five women these measurements were not obtained.

Statistical analyses-Single and multiple regression analyses were used as appropriate to examine relations between the various continuous variables. Pearson's correlation coefficients were calculated for continuous variables with normal distributions. Spearman's rank correlation coefficients were calculated for nonnormally distributed continuous variables. Analysis of variance and covariance was used to determine effects of nominal variables.

\section{Results}

Table I gives the precision of bone density measurements. The mean bone density values (table II) for the women in our study were identical with those obtained in the United States with the same instrumentation. ${ }^{12}$

\section{AGE AND MENOPAUSE (TABLES II AND III)}

Overall, there seemed to be a linear age related decline in bone density in all anatomical sites (L2-4 $\mathrm{r}=-0.32, \mathrm{p}<0.001$; femoral neck $\mathrm{r}=-0.44, \mathrm{p}<0.001$; Ward's triangle $r=-0.53, p<0.001$; trochanteric region $\mathrm{r}=-0.22, \mathrm{p}<0.001)$. But when the results were divided up according to premenopausal and postmenopausal state a different pattern emerged. A slow linear decline in bone density with age was observed in the proximal femur in premenopausal women, while no significant decline was observed in the vertebrae (table II). In postmenopausal women a decline in bone density in all sites was more closely related to time since postmenopause (table II) than to chronological age. No difference was obtained by adjusting chronological age for age at menarche. There was no evidence of any increase in bone density at any age.

The difference between premenopausal and postmenopausal bone density was greatest in Ward's triangle. The patterns of bone loss in various sites are shown in figure 1 .

\section{PHYSICAL VARIABLES (TABLES III AND IV)}

Weight was positively correlated with both vertebral and femoral bone density in only the postmenopausal women. Height was positively related to vertebral bone density alone, and only in premenopausal women.

\section{LIFESTYLE VARIABLES (TABLES III-V)}

No effect on bone density was seen with dietary calcium intake or family history. With respect to other variables, however, differences were seen according to menopausal state.

Premenopausal women-There was no influence 
from pregnancies, breast feeding, previous or current oral contraceptive use, or regular exercise. A clear negative effect of alcohol consumption was seen in all anatomical sites (fig 2). A negative effect of cigarette consumption was also observed, but this was significant only in the vertebrae.

Postmenopausal women-There was a positive influence of breast feeding $(\mathrm{p}<0.01)$ on the vertebral bone density; this seemed to reflect the presence or absence of nulliparity as the influence of breast feeding disappeared when only parous women were analysed. A positive influence of previous oral contraceptive use was observed at all sites. Alcohol and cigarette consumption were without effect. There was, however, a
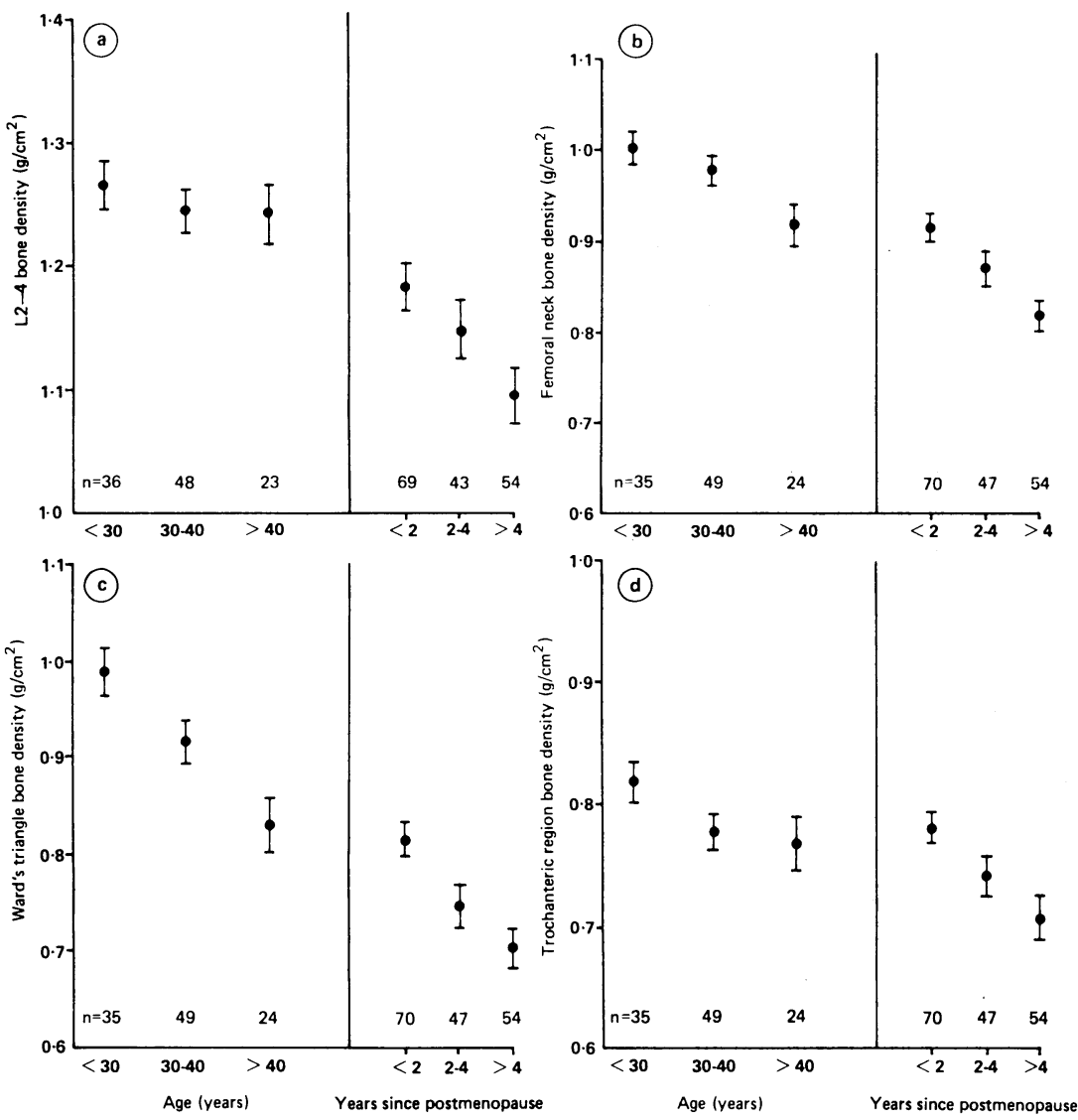

FIG 1-Mean (SEM) bone density (a) in L2-4 vertebrae; (b) in femoral neck; (c) in Ward's triangle; (d) in trochanteric region

TABLE IV - Relation of physical and lifestyle factors to bone density in premenopausal and postmenopausal women

\begin{tabular}{|c|c|c|c|c|c|c|c|}
\hline Site & Height & Weight & Gravidity & $\begin{array}{c}\text { Oral } \\
\text { contraceptive } \\
\text { use } \\
\end{array}$ & $\begin{array}{c}\text { Calcium } \\
\text { intake }\end{array}$ & $\begin{array}{c}\text { Alcohol } \\
\text { intake }\end{array}$ & $\begin{array}{c}\text { Cigarette } \\
\text { consumption }\end{array}$ \\
\hline \multicolumn{8}{|c|}{ Premenopausal women } \\
\hline $\begin{array}{l}\text { Femoral neck: } \\
\mathrm{r}\end{array}$ & & & & & & & \\
\hline $\begin{array}{l}\mathrm{r} \\
\mathrm{p}\end{array}$ & $\begin{array}{l}0.14 \\
\text { NS }\end{array}$ & $\begin{array}{l}0.04 \\
\text { NS }\end{array}$ & $\begin{array}{c}-0 \cdot 19 \\
\text { NS }\end{array}$ & $\begin{array}{l}0.07 \\
\text { NS }\end{array}$ & $\begin{array}{l}0.13 \\
\mathrm{NS}\end{array}$ & $\begin{array}{l}-0.30 \\
<0.005\end{array}$ & $\begin{array}{c}-0 \cdot 10 \\
\text { NS }\end{array}$ \\
\hline \multicolumn{8}{|l|}{ Ward's triangle: } \\
\hline r & $0 \cdot 12$ & 0.02 & $-0 \cdot 19$ & 0.09 & $0 \cdot 15$ & $-0 \cdot 26$ & $-0 \cdot 10$ \\
\hline$p$ & NS & NS & NS & NS & NS & $<0.01$ & NS \\
\hline \multicolumn{8}{|l|}{ Trochanteric region: } \\
\hline $\begin{array}{l}\mathrm{r} \\
\mathrm{p}\end{array}$ & $0 \cdot 12$ & 0.13 & $-0 \cdot 19$ & -0.02 & 0.09 & -0.34 & $-0 \cdot 11$ \\
\hline \multicolumn{7}{|l|}{ Vertebrae, L2-4: } & NS \\
\hline r & $0 \cdot 23$ & $0 \cdot 18$ & $-0 \cdot 08$ & 0.07 & $0 \cdot 11$ & $-0 \cdot 20$ & $-0 \cdot 24$ \\
\hline $\mathrm{p}$ & $<0.025$ & NS & NS & NS & NS & $<0.05$ & $<0.025$ \\
\hline \multicolumn{8}{|c|}{ Postmenopausal women } \\
\hline Femoral neck: & & & & & & & \\
\hline $\mathrm{r}$ & $0 \cdot 15$ & $0 \cdot 22$ & $0 \cdot 08$ & $0 \cdot 19$ & $0 \cdot 11$ & 0.01 & -0.02 \\
\hline $\mathrm{p}$ & NS & $<0.005$ & NS & $<0.02$ & NS & NS & NS \\
\hline \multicolumn{8}{|l|}{ Ward's triangle: } \\
\hline $\mathbf{r}$ & 0.09 & $0 \cdot 18$ & 0.08 & $0 \cdot 20$ & $0 \cdot 13$ & -0.01 & -0.04 \\
\hline$\underset{\text { Trochanteric region: }}{\mathbf{p}}$ & NS & $<0.05$ & NS & $<0 \cdot 01$ & NS & NS & NS \\
\hline \multicolumn{8}{|l|}{ Trochanteric region: } \\
\hline $\mathrm{p}$ & NS & $<0.001$ & NS & $<0.05$ & NS & NS & NS \\
\hline \multicolumn{8}{|l|}{ Vertebrae, L2-4: } \\
\hline $\mathrm{r}$ & $0 \cdot 15$ & $0 \cdot 24$ & $0 \cdot 11$ & $0 \cdot 20$ & 0.07 & 0.17 & -0.05 \\
\hline $\mathbf{p}$ & NS & $<0.005$ & NS & $<0.02$ & NS & NS & NS \\
\hline
\end{tabular}

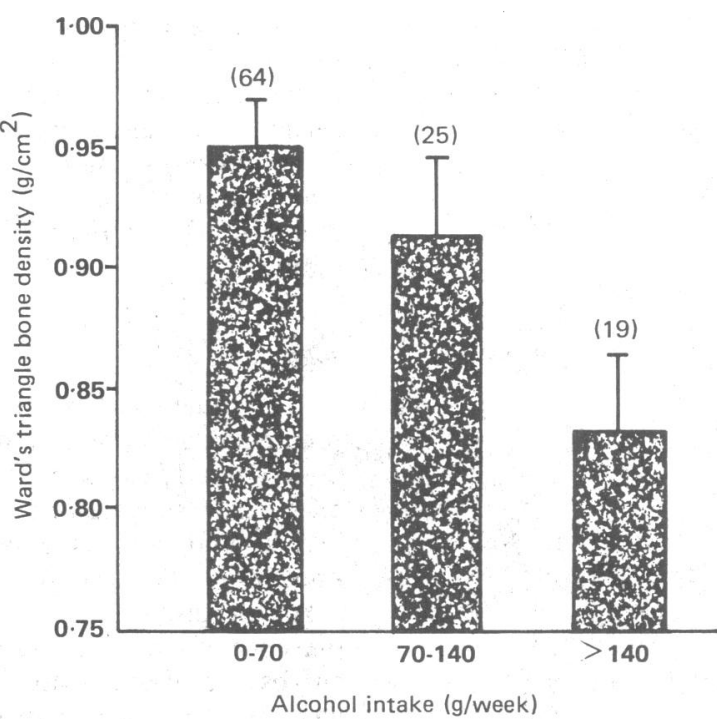

FIG 2-Mean (SEM) bone density in Ward's triangle in premenopausal women with various alcohol intakes grouped to show effects of less than one, one to two, and more than two standard drinks per day $(p<0.05$ with age as a covariate $)$

significant difference $(\mathrm{p}<0.05)$ in bone density in the proximal femur (neck and Ward's triangle) between women who did and did not take regular exercise when time since menopause and body weight were used as covariates (table V).

\section{PREDICTION OF BONE DENSITY}

Among those factors that were significantly related to bone density, no multiple regression could account for more than one third of the variance in either premenopausal or postmenopausal women. Thus bone density could not be predicted accurately from any combination of factors.

\section{Discussion}

Our results clarify some important issues. Firstly, peak bone density seems to have been achieved by the end of or soon after linear skeletal growth. It seems likely that genetic influences are an important determinant of peak bone mass, ${ }^{13}$ and this might explain the positive relation between vertebral bone density and height in the premenopausal women. In agreement with others ${ }^{1781415}$ we saw no evidence of skeletal consolidation in the third or fourth decade, which has been suggested. Garn reported an increase in cortical density in the third decade, ${ }^{6}$ but he assessed only peripheral cortical bone and thus any changes in intracortical porosity would not have been taken into account. Our measurements were made in the axial skeleton, where there is an appreciable amount of trabecular as well as cortical bone. We recognise the limitations of cross sectional studies in that a small increase in bone density in the third or fourth decade may be masked, though longitudinal studies suggest there is no evidence of an increase. ${ }^{16}$

Secondly, the menopause has the single greatest effect on bone density in any site. The hypothesis of Riggs and Melton ${ }^{5}$ proposes two types of osteoporosis. Type 1 results from the menopause and is mainly characterised by vertebral fractures; type 2 results from an age related decline in renal endocrine function and particularly includes femoral neck fractures. We, however, have now shown a major effect of the menopause on bone density in the proximal femur, and this is related to the incidence of fractures. ${ }^{11}$ Thus the menopause is clearly related to all types of postmenopausal osteoporotic fractures. This strongly suggests that preventing postmenopausal bone loss would have a dramatic effect on the incidence of fractures in the 
TABLE V-Mean $(S D)$ bone density $\left(\mathrm{g} / \mathrm{cm}^{2}\right)$ in women with or without a positive history of regular exercise, family history of osteoporosis, and history of breast feeding

\begin{tabular}{|c|c|c|c|c|}
\hline & \multicolumn{2}{|c|}{ Premenopausal women } & \multicolumn{2}{|c|}{ Postmenopausal women } \\
\hline & Positive & Negative & Positive & Negative \\
\hline $\begin{array}{l}\text { Vertebrae, L2-4 } \\
\text { Femoral neck } \\
\text { Ward's triangle } \\
\text { Trochanteric region }\end{array}$ & $\begin{array}{l}1 \cdot 24(0 \cdot 12) \\
0.96(0 \cdot 12) \\
0.91(0 \cdot 16) \\
0 \cdot 78(0 \cdot 10)\end{array}$ & $\begin{array}{l}\text { Exercise } \\
1 \cdot 28(0 \cdot 12) \\
0.98(0 \cdot 13) \\
0.93(0 \cdot 16) \\
0.80(0 \cdot 11)\end{array}$ & $\begin{array}{l}1 \cdot 15(0 \cdot 16) \\
0 \cdot 89(0 \cdot 14) \\
0 \cdot 78(0 \cdot 16) \\
0 \cdot 75(0 \cdot 13)\end{array}$ & $\begin{array}{l}1 \cdot 14(0 \cdot 18) \\
0 \cdot 85(0 \cdot 12)^{\star} \\
0 \cdot 73(0 \cdot 15)^{\star \star} \\
0 \cdot 74(0 \cdot 12)\end{array}$ \\
\hline $\begin{array}{l}\text { Vertebrae, L2-4 } \\
\text { Femoral neck } \\
\text { Ward's triangle } \\
\text { Trochanteric region }\end{array}$ & $\begin{array}{l}1 \cdot 25(0 \cdot 12) \\
0.97(0 \cdot 11) \\
0 \cdot 93(0 \cdot 16) \\
0 \cdot 78(0 \cdot 10)\end{array}$ & $\begin{array}{r}\text { Family history } \\
1.25(0.13) \\
0.97(0 \cdot 13) \\
0.91(0 \cdot 17) \\
0 \cdot 79(0 \cdot 11)\end{array}$ & $\begin{array}{l}1 \cdot 13(0 \cdot 14) \\
0.85(0 \cdot 13) \\
0.75(0 \cdot 15) \\
0 \cdot 74(0 \cdot 13)\end{array}$ & $\begin{array}{l}1 \cdot 16(0 \cdot 18) \\
0 \cdot 88(0 \cdot 14) \\
0 \cdot 77(0 \cdot 16) \\
0 \cdot 75(0 \cdot 12)\end{array}$ \\
\hline $\begin{array}{l}\text { Vertebrae, L 2-4 } \\
\text { Femoral neck } \\
\text { Ward's triangle } \\
\text { Trochanteric region }\end{array}$ & $\begin{array}{l}1.26(0 \cdot 13) \\
0.95(0 \cdot 11) \\
0.90(0.03) \\
0.79(0 \cdot 11)\end{array}$ & $\begin{array}{r}\text { Breast feeding } \\
1.25(0.12) \\
0.98(0.12) \\
0.93(0.17) \\
0.79(0.11)\end{array}$ & $\begin{array}{l}1 \cdot 18(0 \cdot 16) \\
0 \cdot 88(0 \cdot 13) \\
0 \cdot 78(0 \cdot 16) \\
0 \cdot 76(0 \cdot 12)\end{array}$ & $\begin{array}{l}1.11(0.17)^{\star \star \star} \\
0.86(0.13) \\
0.74(0.16) \\
0.73(0.12)\end{array}$ \\
\hline
\end{tabular}

${ }^{\star} \mathrm{p}<0.05 ;{ }^{\star \star} \mathrm{p}=0.25 ;{ }^{\star \star \star} \mathrm{p}<0.025$

proximal femur - as has been predicted ${ }^{17}$-as well as the spine. Our observation that weight is positively correlated with bone density in postmenopausal women may reflect the fact that adipose tissue is the main site of adrenal androstenedione conversion to oestrone in these women.

Thirdly, there is a gradual age related decline in bone density in the femoral neck and Ward's triangle before the menopause but no appreciable loss of vertebral bone density at this time. These findings are in agreement with other reports. ${ }^{814}$ is In contrast Riggs et al reported a linear decline in bone density in both spine and femoral neck throughout adult life. The reason for these differences is not clear. The differing effect of age between the vertebrae and proximal femur is interesting. It may be in part due to the different compositions of trabecular and cortical bone in these sites. This may also explain why no age effect is seen in the trochanteric region. It may also reflect differences between the metabolic activity of the trabecular bone in the vertebrae and the proximal femur, as has been shown between other anatomical sites. ${ }^{18} 19$

Fourthly, alcohol intake clearly has a deleterious effect on bone density in young women, which has hitherto been unrecognised. It is known that alcoholism is associated with osteoporosis, ${ }^{20-22}$ perhaps because of a general toxic effect on the bone forming cells. ${ }^{23}{ }^{24}$ Since the effect of alcohol would be additive to the age related decline in proximal femoral bone density in premenopausal women between five and eight standard $(10 \mathrm{~g}$ ethanol) drinks a day at age 50 could take the bone density below the theoretical fracture threshold. Cigarette smoking has previously been associated with an increase in the incidence of osteoporosis, ${ }^{25}$ and we noted a significant negative effect of smoking on bone density in the vertebrae.

In the premenopausal women dietary calcium intake and participation in regular exercise had no influence on bone density in any site. A beneficial and additive effect of dietary calcium intake and exercise on the premenopausal skeleton has recently been reported. ${ }^{26}$ While we recognise that our assessments of these two variables were superficial in comparison we would still have expected to observe some effect if these factors were of any substantial influence. But even when comparing the extremes of the groups we were unable to detect an effect. We also found no relation between calcium intake and bone density in postmenopausal women, which agrees with previous reports. ${ }^{27} 28$

We observed a positive though small influence of regular exercise on the proximal femur in postmenopausal women. This would presumably be the result of weight bearing exercise, and we are now conducting detailed studies of exercise levels and postmenopausal bone density. We saw a negative effect of nulliparity on the vertebrae and a positive effect of oral contraceptive use on bone density in all sites, but only in postmenopausal women. Such influences have previously been reported to affect the peripheral skeleton. ${ }^{29}$ It seems that the influence of several lifestyle factors on bone density is observed only after the menopause when the overriding effect of ovarian function on the skeleton is removed.

We believe that our failure to find an influence of family history of osteoporosis on bone density may be due to the difficulty in obtaining an accurate family history, particularly with regard to spinal osteoporosis.

Finally, while we recognise the shortcomings of subjective assessments of risk factors, it is clear that bone density, and hence risk of osteoporotic fracture, cannot be predicted accurately from any combination of simple physical and lifestyle factors. To reduce the incidence of osteoporosis it is essential that preventive treatment is given to those women at greatest risk of developing the disease. It has been suggested that a combination of simple biochemical tests can predict fast bone losers among menopausal women, ${ }^{30}$ but this is not necessarily of help in deciding who to treat if the bone density is not known. A woman with a low bone density who is losing bone slowly may be at greater risk than a fast bone loser with a high bone density. At present, direct bone density measurement in the clinically relevant sites in the axial skeleton seems to be the best way to select women for preventive treatment for postmenopausal osteoporosis; those with a low bone density are at greatest risk of developing the disease irrespective of rate of bone loss.

These studies were supported by the Heart Disease and Diabetes Research Trust, UK.

1 Meema S, Meema HE. Menopausal bone loss and estrogen replacement. Ist f Med Sci 1976;12:601-6.

2 Lindsay R, Hart DM, Aitken JM, MacDonald EB, Anderson JB, Clarke AC. Long-term prevention of postmenopausal osteoporosis by oestrogen. Lancet 1976;i:1038-41.

3 Genant HK, Cann CE, Ettinger B, Gordan GS. Quantitative computed tomography of vertebral spongiosa: a sensitive method for detecting early bone loss after oophorectomy. Ann Intern Med 1982;97:699-705.

4 Stevenson JC, Lees B, Banks LM, Whitehead MI. Assessment of therapeutic options for prevention of bone loss. In: Christiansen C, Johansen JS, Riis options for prevention of bone loss. In: Christiansen C, Johansen J
BJ, eds. Osteoporosis 1987. Viborg: Norhaven A/S, 1987:489-93.

5 Riggs BL, Melton LJ. Evidence for two distinct syndromes of involutional osteoporosis. Am J Med 1983;75:899-901.

6 Garn SM. The earlier gain and later loss of cortical bone. Springfield IIl: Thomas, 1970

7 Riggs BL, Wahner HW, Seeman E, et al. Changes in bone mineral density of the proximal femur and spine with aging. $\mathcal{F}$ Clin Invest 1982;70:716-23.

8 Gallagher JC, Goldger D, Moy A. Total body calcium in normal women: effect of age and menopause status. $\mathcal{F}$ Bone Min Res 1987;2:491-6.

9 Krolner B, Nielsen SP. Bone mineral content of the lumbar spine in normal and osteoporotic women: cross-sectional and longitudinal studies. $\mathrm{Clin} \mathrm{Sci}$ 1982;62:329-36.

10 Melton LJ, Wahner HW, Richelson LS, O'Fallon WM, Dunn WL, Riggs BL. Bone density specific fracture risk: a population based study of the relationship between osteoporosis and vertebral fractures. $f$ Nucl Med relationship

11 Melton LJ, Wahner HW, Richelson LS, O'Fallon WM, Riggs BL. Osteoporosis and the risk of hip fracture. Am 7 Epidemiol 1986;124:254-61.

12 Mazess RB, Barden HS, Ettinger M, et al. Spine and femur density using dualphoton absorptiometry in US white women. Bone and Mineral 1987;2:211-9.

3 Smith DM, Nance WE, Kang KW, Christian JC, Johnston CC. Genetic Smith DM, Nance WE, Kang KW, Christian JC, Johnston CC.
factors in determining bone mass. $\mathcal{F}$ Clin Invest 1973;52:2800-8.

14 Hui SL, Slemenda CW, Johnston CC, Appledorn CR. Effects of age and menopause on vertebral bone density. Bone and Mineral 1987;2:141-6.

15 Schaadt O, Bohr H. Different trends of age-related diminution of bone mineral content in the lumbar spine, femoral neck and femoral shaft in women. Calcif Tissue Int 1988;42:71-6.

16 Riggs BL, Wahner HW, Melton LJ, Richelson LS, Judd HL, Offord KP. Rates of bone loss in the appendicular and axial skeletons of women. $7 \mathrm{Clin}$ Invest 1986;77:1487-91.

17 Stevenson JC. Post-menopausal bone loss and osteoporosis. In: Zichella L, Whitehead MI, van Keep PA, eds. The climacteric and beyond. Carnforth: Parthenon, 1988:125-35.

18 Seeman E, Wahner HW, Offord KP, Kumar R, Johnson WJ, Riggs BL. Differential effects of endocrine dysfunction on the axial and the appendicular skeleton. $\mathcal{F}$ Clin Invest 1982;69:1302-9.

19 Stevenson JC, Banks LM, Spinks TJ, et al. Regional and total skeletal measurements in the early postmenopause. $f$ Clin Invest 1987;80:258-62.

20 Saville PD. Alcohol related skeletal disorders. Ann N Y Acad Sci 1975;252 287-91.

21 Israel Y, Orrego H, Holt S, et al. Identification of alcohol abuse: thoracic fractures, routine chest X-ray as indication of alcoholism. Alcoholism 1980;4:420-2.

22 Feitelberg S, Epstein S, Ismail F, D'Amanda C. Deranged bone mineral metabolism in chronic alcoholism. Metabolism 1987;36:322-6. 
23 Baran DT, Teitelbaum SL, Berfield MA, et al. Effects of alcohol ingestion on bone and mineral metabolism in rats. Am f Physiol 1980;238: E507-10.

24 Peng TC, Garner SC, Frye GD, et al. Evidence of a toxic effect of ethanol on bone in rats. Alcoholism 1982;6:96-9.

25 Daniell HW. Osteoporosis of the slender smoker: vertebral compression fractures and loss of metacarpal cortex in relation to postmenopausal smoking and lack of obesity. Arch Intern Med 1976;136:298-304.

26 Kanders B, Dempster DW, Lindsay R. Interaction of calcium nutrition and physical activity on bone mass in young women. Journal of Bone and Mineral Research 1988;3:145-9.

27 Riggs BL, Wahner HW, Melton LJ, Richelson LS, Judd HL, O'Fallon WM
Dietary calcium intake and rate of bone loss in women. $\mathcal{f}$ Clin Inves 1987;80:979-82.

28 Stevenson JC, Whitehead MI, Padwick M, et al. Dietary intake of calcium and postmenopausal bone loss. Br Med f 1988;297:15-7.

29 Goldsmith NF, Johnston JO. Bone mineral: effects of oral contraceptives, pregnancy, and lactation. $\mathcal{F}$ Bone foint Surg 1975;57A:657-68.

30 Christiansen C, Riis BJ, Rodbro P. Prediction of rapid bone loss in postmenopausal women. Lancet 1987; i:1105-8.

(Accepted 6 February 1989)

\section{Pulmonary oedema after acute asphyxia in a child}

M Boykett

Pilgrim Hospital, Boston, Lincolnshire PE21 9QS

$M$ Boykett, FFARCS, anaesthetic registrar

Correspondence to: Leicester Royal Infirmary, Leicester LE1 5WW.

BrMed f 1989;298:928 cating acute upper airway obstruction.

\section{Case report}

I report a case of severe pulmonary oedema compli-

A previously well 8 year old boy was found having choked on a vitamin tablet (Sanatogen Junior, Fisons). He was apnoeic, unresponsive, and cyanosed. During attempts at basic airway resuscitation he coughed up bloodstained mucus before recovering consciousness.

During the next one to two hours, after admission to hospital, he developed tachypnoea, cyanosis, and bilateral lung crepitations. He had radiological signs of florid bilateral pulmonary oedema without cardiomegaly. Oxygen, ampicillin, and hydrocortisone were given, and a rigid bronchoscopy was performed to ensure that there was no residual foreign body. Anaesthesia and bronchoscopy were rendered difficult by a profuse amount of bloodstained froth pouring from the larynx. No foreign body or vomit was found, and he was given intensive care.

With intermittent positive pressure ventilation with $5 \mathrm{~cm} \mathrm{H}_{2} \mathrm{O}$ positive end expiratory pressure and an inspired fractional oxygen concentration of 0.6 his oxygen saturation was initially $87 \cdot 5 \%$ (arterial oxygen tension $9 \cdot 1 \mathrm{kPa}$ ). The arterial $\mathrm{pH}$ of $7 \cdot 18$ reflected mixed metabolic and respiratory acidosis. His general condition, breathing, and arterial blood gas measurements all improved rapidly over the next six to 12 hours. Subsequently, he maintained a normal arterial oxygen tension during spontaneous breathing at 5-10 $\mathrm{cm}$ continuous positive airway pressure and an inspired oxygen fractional concentration of $0 \cdot 25-0 \cdot 30$. Extubation was delayed for two days because of a persistent pink tracheal aspirate and until the radio- logical abnormalities had resolved. Further recovery was complete and unremarkable.

\section{Comment}

An accurate diagnosis proved elusive. Fluid overload and primary left ventricular failure were dismissed as possible causes, and pulmonary aspiration and chemical pneumonitis were considered to be the main differential diagnoses. The history and clinical findings, however, were not characteristic of aspiration. The manufacturer of the tablet and Guy's Hospital's Poisons Unit were consulted, but chemical irritation was excluded as a likely cause.

Similar cases of postobstructive pulmonary oedema have occurred in, for example, laryngospasm, ' croup, and epiglottitis. ${ }^{2}$ Most cases were in children but were less severe than the one reported here, and none was associated with an impacted foreign body. Brown reviewed previous reports and proposed mechanisms by which airway obstruction may cause pulmonary oedema. ${ }^{3}$ These include negative intrathoracic pressure causing transiently low pulmonary interstitial pressure or impaired left ventricular function, or both, and hypoxic postcapillary and venous constriction. Treatment with oxygen alone may be sufficient, but a brief period of tracheal intubation and assisted ventilation may be necessary. Upper airway obstruction occurs frequently, and doctors should be aware of this unfamiliar complication.

I thank Dr M Bexton and Dr A Syed for their help in managing this patient; Dr A Vaizey for permission to report on the patient; Mrs M Chambers and Miss J Norton for typing.

1 Lee KWT, Downes JJ. Pulmonary edema secondary to laryngospasm in children. Anesthesiology 1983;59:347-9.

2 Galvis AG, Stool SE, Bluestone CD. Pulmonary edema following relief of upper airway obstruction. Ann Otol Rhinol Laryngol 1980;89:124-8.

3 Brown RE. Negative pressure pulmonary edema. In: Berry FA, ed. Anesthetic management of difficult and routine pediatric patients. New York: Churchill Livingstone, 1986:168-79.

(Accepted 9 December 1988)

\section{Hallucinations after epidural buprenorphine}

\author{
M MacEvilly, C O'Carroll
}

Blackrock Clinic, Blackrock, County Dublin, Republic of Ireland M MacEvilly, FFARCSI, consultant anaesthetist C O'Carroll, SRN, sister, Nightingale unit

Correspondence to: $\mathrm{Dr}$ MacEvilly.

BrMed F 1989;298:928-9
Buprenorphine, a mixed central nervous system opiate agonist-antagonist, is virtually free of hallucinatory effects in parenteral formulation, the incidence being $0 \cdot 1 \% .^{\prime}$ Epidural administration of buprenorphine, however, may not be quite as free of these side effects.

\section{Case reports}

Case 1-A 40 year old woman underwent fusion of the posterior lumbar bodies at L4-5 under general anaesthetic. Postoperatively she was given $150 \mu \mathrm{g}$ buprenorphine every eight to 12 hours as needed through an epidural cannula. Forty eight hours after surgery and after a total dose of buprenorphine of $900 \mu \mathrm{g}$ she complained of nightmares (table). The symptoms occurred only at night and within 10 minutes after the drug was topped up. She was also distressed by the shadows in the room and became anxious when left alone. The symptoms disappeared once buprenorphine was stopped.

Case 2-A 38 year old woman underwent posterior spinal fusion between the transverse processes (L1-3). Postoperatively analgesia was maintained through an epidural cannula with $150 \mu \mathrm{g}$ buprenorphine every eight to 12 hours as necessary. After 48 hours she complained of a recurring dream in which she recalled a frightening incident from her past. The dream recurred so vividly at night that she became extremely distressed. She had received a total dose of $750 \mu \mathrm{g}$ 